\title{
Desain Saklar Otomatis Untuk Kontrol Peralatan Listrik di Bangunan
}

\author{
Gusti Agung Ayu Putri, Ni Made Ika Marini Mandenni \\ Program Studi Teknologi Informasi, Fakultas Teknik, Universitas Udayana \\ Bukit Jimbaran, Bali - Indonesia \\ e-mail : agung.ayuputri@unud.ac.id, made.ika.mm@gmail.com
}

\begin{abstract}
Abstrak
Pemakaian peralatan listrik di gedung sudah menjadi kebutuhan primer. Sangat sulit untuk menemukan sebuah gedung tanpa ada peralatan listrik didalamnya. Saklar adalah antarmuka yang digunakan untuk on/off peralatan listrik. Model saklar yang telah dikembangkan cukup banyak, mulai dari model saklar manual sampai dengan saklar yang bisa dikontrol dari jarak jauh. Penelitian ini mencoba untuk mengembangkan sebuah model saklar yang ditanamkan pada gedung. Hal ini membuat gedung mampu untuk melakukan kontrol peralatan listrik secara aktif. Gedung hanya mengaktifkan peralatan listrik bila ada penghuni yang beraktifitas disana. Sebuah simulasi berbasis mikrokontroler Arduino Mega 2560 dibuat untuk pengujian tahap awal model saklar yang didesain. Hasil pengujian menunjukkan model saklar otomatis mampu untuk mengendalikan peralatan listrik secara otomatis berdasarkan deteksi terhadap lingkungan dunia nyata sistem kelistrikan di bangunan.
\end{abstract}

Kata kunci : smart building, saklar otomatis, mikrokontroler arduino mega 2560

\begin{abstract}
Nowadays, appliances has become a primary goods to support inhabitants activities. Here is very difficult to notice a building without any electrical equipment.Appliances make use plug as interface for turn on or turn off.There are many plug models that have been developed, from manual plug models to switches that can be controlled remotely. We studied development of a switch that can be embedded in the building, then namely as automatic plug.Automatic plug assigns the building workmanlike actively controlling electrical equipment. Smart building will only switch on appliances if the room in the building occupied. A simulation based on the microcontroller Arduino Mega 2560 is built to evaluate the ability of implicit interaction and automatic plug behaviors. The test shows that the automatic plug is able to automatically control appliances based on the sensing of the real world environment of the building electricity system.
\end{abstract}

Keywords: smart building, automatic plug, microcontroller Arduino Mega 2560

\section{Pendahuluan}

Konvergensi teknologi komputer, sensor, aktuator, dan telekomunikasi telah memungkinkan untuk pengembangan lingkungan digital yang cerdas. Kemajuan terkait lingkungan digital juga membuat menyatunya dunia nyata dengan dunia virtual secara transparan yang dimungkinkan karena kemajuan dan miniaturisasi perangkat microelectronic, dengan susunan yang terdiri dari peralatan sensor, aktuator, microprocessor dan telekomunikasi. Miniaturisasi teknologi juga memberikan kemampuan untuk menanamkan teknologi tersebut diberbagai objek dunia nyata. Teknologi ini kemudian lebih dikenal dengan nama pervasive system, namun ada beberapa literatur yang menyebutnya dengan nama cyber physical systems.

Salah satu bidang penelitian pervasive system adalah penciptaan bangunan cerdas pada domain pemakain listrik digedung/bangunan. Pervasive system digunakan untuk membangun smart building yang mampu mengelola penggunaan peralatan listrik. Peralatan listrik digedung wajib dikelola secara baik mengingat semakin meningkatnya pemakaian listrik oleh penghuni bangunan. Pervasive sistem dapat menggunakan informasi-informasi yang ada 
pada sistem kelistrikan dibangunan sebagai dasar manajemen pemakaian peralatan listrik disana.

Smart building didefinisikan sebagai gedung yang mampu mengelola peralatan listrik dibangunan menggunakan metode pengindraan lingkungan sekitar gedung, mampu mengelola pemakaian peralatan listrik penghuni gedung,dan melakukan on/off peralatan tersebut secara mandiri[1]. Smart building menggunakan sensor untuk mengindra dan mengumpulkan informasi dari lingkungan bangunan, kemudian menggunakan microprocessor untuk melakukan proses komputasi terhadap isyarat yang diterimanya dari sensor. Microprocessor dapat memerintahkan aktuator untuk melakukan on/off peralatan listrik, jika ada keputusan adaptasi lingkungan pemakaian peralatan listrik tersebut. Pervasive system pada smart building mengimplementasikan Internet of things jika peralatan listrik berada dibangunan secara tersebar di setiap ruangan.

Penelitian di bidang smart building bukanlah sesuatu yang baru, mengingat telah majunya teknologi mikrokontroler, sehingga banyak penelitian yang terkait hal ini juga banyak dilakukan. Sebagai contoh, Masykur, mencoba untuk mengembangkan web based sistem untuk mengendalikan peralatan rumah tangga [2], sedangkan Romoadhon menggunakan smartphone untuk tujuan yang sama [3]. Penelitian Iskandar hampir sama dengan Romoadhon yaitu menggunakan smartphone sebagai kontrol, hanya saja berfokus pada khusus kontrol penerangan buatan [4]. Penelitian Masykur, Romoadhon, dan Iskandar berfokus pada pengembangan sistem kontrol dari jarak jauh. Penelitian Azifah agak berbeda, yaitu mengembangkan sistem kontrol penerangan buatan berbasis websocket dan pemantauan penerangan alami [5], hanya saja, dalam penelitiannya, Azifah hanya berfokus pada kontrol penerangan.

Penelitian ini mencoba untuk mengembangkan sebuah model saklar otomatis yang dikendalikan langsung oleh smart building. Smart building secara aktif sebagai skalar otomatis dan mampu berinteraksi dengan penghuni bangunan dan peralatan listrik secara implisit. Otomatisasi yang diterapkan menjadi berbeda dengan penelitian diatas, dimana kontrol peralatan masih dilakukan oleh penghuni bangunan walaupun dari jarak jauh.

Sensor merupakan fungsi kunci untuk pengembangan sistem saklar otomatis, yang digunakan sebagai penghubung antara dunia nyata domain kelsitrikan dibangunan dengan lingkungan pervasive system. Artikel ini membahas pengembangan simulasi kontrol peralatan listrik berbasis mikrokontroler Arduino Mega 2560. Sensor-sensor dipilih berdasarkan informasi yang digunakan oleh saklar otomatis smart building sistem manajemen peralatan listrik di sebuah gedung.

\section{Metode dan Perancangan Sistem}

Simulasi sistem saklar otomatis dikembangkan menggunakan mikrokontroler arduino mega 2560 dengan tujuan sebagai tahap awal pengujian kemampuan smart building untuk paham pada lingkungan dunia nyata sistem kelistrikan di dalam gedung. Saklar otomatis digunakan oleh smart building untuk berinterkasi secara implisit dengan penghuni dan lingkungan phisik gedung. Adaptasi on/off peralatan listrik dilakukan berdasarkan kehadiran penghuni bangunan dan penggunaan ruangan di suatu bangunan. Skalar otomatis menghidupkan peralatan listrik hanya jika ada penghuni disana. Tujuannya adalah untuk mengurangi pemakaian listrik pada saat ruangan dalam keadaan tidak berpenghuni.

Kecerdasan yang dimiliki oleh bangunan dikembangkan melalui pengintegrasian banyak smart object yang paham terhadap dimensi informasi energi listrik digedung. Smart building bertugas untuk mengelola smart object. Model smart building yang ingin dikembangkan seperti ditunjukkan pada gambar 1 .

Rancang-bangun simulasi dan pengujian sistem saklar otomatis menggunakan peralatan sensor yang terpasang onboard pada mikrokontroler Arduino mega 2560, dapat dilihat pada Gambar 2. Selain itu, peralatan listrik juga digantikan dan disimbolkan dengan penunjukkan kondisi on/off lampu Led yang juga terpasang onboard di mikrokontroler tersebut. 


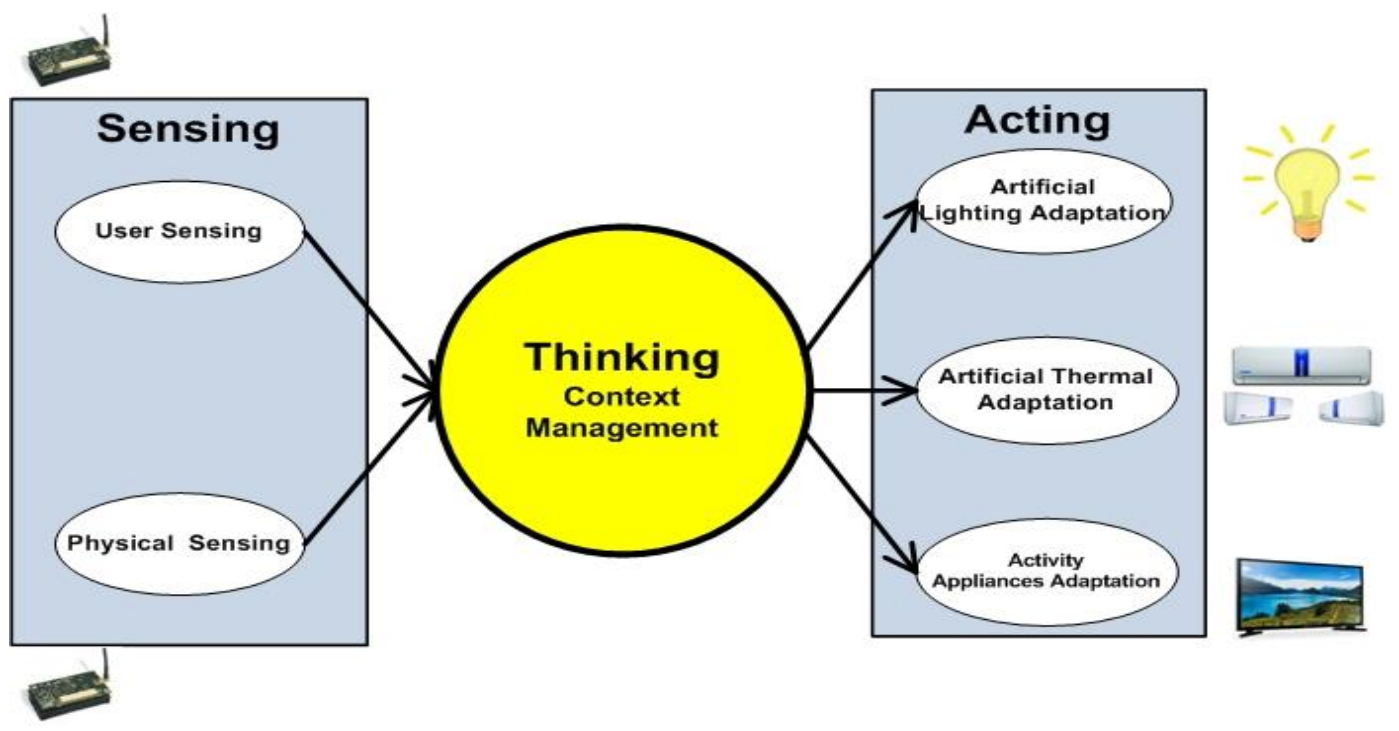

Gambar 1. Model Smart Building Pemakaian Peralatan Listrik

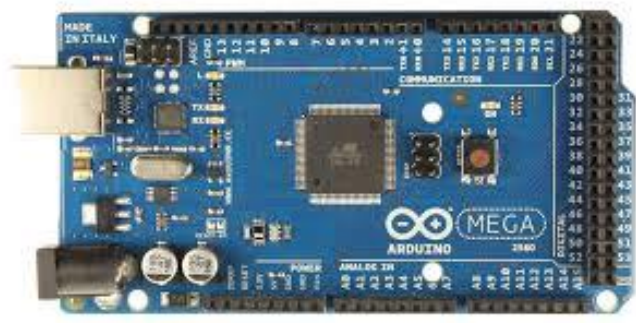

Gambar 2. Mikrokontroler Arduino Mega 2560

Smart building menggunakan sensor untuk mengindra dan mengumpulkan informasi tentang kondisi lingkungan bangunan. Sensor juga merupakan alat yang digunakan oleh saklar otomatis untuk berinteraksi secara implisit dengan lingkungannya. Keseluruhan infomasi yang dikumpulkan oleh sensor digunakan sebagai dasar manajemen peralatan listrik. Pemetaan dimensi informasi lingkungan sistem kelistrikan dibangunan dengan sensor dapat dilihat pada Tabel 1.

Tabel . 1. Korelasi antara sensor dengan informasi yang digunakan oleh smart building

\begin{tabular}{rlll}
\hline No & \multicolumn{1}{c}{ Informasi } & \multicolumn{1}{c}{ Komponen } & \multicolumn{1}{c}{ Ket } \\
\hline 1. & pengindraan kehadiran penghuni & keypad arduino & untuk ruangan prifat \\
& bangunan & & \\
\hline 2. & $\begin{array}{l}\text { pengindraan kehadiran penghuni } \\
\text { bangunan }\end{array}$ & ir-pushbutton & untuk ruangan publik \\
\hline 3. & pengindraan terang-gelap diruangan & photo diode & penerangan alami \\
\hline 4. & pengindraan suhu ruangan & LM35 & temperatur alami \\
\hline 5. & pengindraan fungsi ruangan & Arduino & hardcode onboard \\
\hline 6. & pengindraan tipe ruangan & Arduino & hardcode onboard \\
\hline
\end{tabular}

Smart building menggunakan nilai dari keenam dimensi informasi pada Tabel 1 untuk memahami kondisi lingkungan gedung dan kemudian memanfaatkannya sebagai dasar 
manajemen penggunaan peralatan listrik secara rasional. Keenam dimensi informasi digunakan untuk penyusunan aturan yang ditanamkan pada saklar otomatis sistem manajemen peralatan listrik pada gedung.

\section{Kajian Pustaka}

\subsection{Konsep Ruang dan Pengaruhnya Pada Pemakaian Peralatan Listrik}

Secara umum, sebuah aktifitas dilaksanakan pada ruang-ruang khusus yang memang sudah dipersiapkan agar aktifitas tersebut bisa berlangsung dengan baik. Faktor peralatan pendukung kegiatan, kondisi udara dan penerangan pada lingkungan ruangan akan sangat mempengaruhi kenyamanan didalam pelaksanaan aktifitas. Jika pembentukan ruangan telah direncanakan dengan baik, maka sesungguhnya lingkungan alami bangunan sudah mampu mengakomodasi kebutuhan tersebut.

Namun pada kenyataannya, bangunan tidak selalu mampu menyediakan lingkungan alami yang konstan dan nyaman didalam mendukung pelaksanaan aktifitas penghuninya. Hal ini terjadi karena beberapa hal, diantaranya faktor pemilihan bahan bangunan yang kurang sesuai dengan kondisi alamiah lingkungan bangunan. Contoh lainnya adalah kurang tepatnya desain sistem pasif lingkungan bangunan.

Desain sistem penerangan, penghawaan dan peralatan listrik sebagai alat pendukung aktifitas merujuk kepada fungsi ruangan dan dapat didesain melalui tiga tingkatan pelaksanaan. Tingkat pertama adalah pendekatan rancangan dasar bentuk dan bahan bangunan. tingkat kedua adalah menerapkan sistem pasif. Tingkat ketiga adalah perencanaan sistem mekanik dan elektrik kedalam bangunan. Secara umum, desain ketiga sistem diatas akan selalu melibatkan ketiga tingkatan ini.

Kesalahan desain pada tingkat pertama dan kedua akan menyebabkan pembebanan yang lumayan tinggi pada desain tingkat ketiga. Ketika perancangan tingkat pertama dan kedua didesain bertentangan dengan kondisi alamiah lingkungan bangunan, maka perancangan ditingkat ketiga akan mengambil tanggung jawab untuk menyediakan keadaan nyaman yang disesuaikan dengan kebutuhan penghuni. Hal ini mengakibatkan peningkatan pemakain listrik disana. Solusi yang dapat dipilih untuk mengatasi peningkatan tersebut adalah dengan mengimplementasikan pervasive system untuk melakukan pengelolaan dan pengontrolan pemakaian peralatan listrik di gedung.

\subsection{Pervasive System Pada Sistem Kelistrikan di Bangunan}

Mark Weiser pada tahun 1991 memperkenalkan terminologi Pervasive Computing/Ubiquitous Computing maksudnya adalah menghilangnya computer. Menghilang disini diartikan menghilang secara fisik computer dan menghilang secara mental [6]. Computer dikatakan menghilang secara fisik karena pada era itu ukuran computer cukup besar sehingga terlihat langsung oleh pemakai, akan tetapi di jaman saat ini peralatan tersebut bisa ditanamkan pada peralatan lain, sebagai contoh smart phone dan microwave, sehingga wujud computer di era dulu sudah tidak terlihat secara langsung. Computer juga dikatakan menghilang secara mental, artinya pemakai tidak menyadari adanya proses komputasi yang terjadi disekitarnya karena tidak terlihatnya perangkat computer secara fisik.

Visi Mark Weiser tersebut sudah mulai banyak terwujud karena semakin majunya perangkat Teknologi Informasi yang ada di era sekarang. Teknologi yang memungkinkan terwujudnya Pervasive Systems adalah teknologi perangkat smart things, teknologi telekomunikasi tanpa kabel, teknologi microprocessor, teknologi software dan teknik HumanComputer Interaction yang semakin baik. Pengintegrasian peralatan tersebut dalam satu kesatuan sistem dapat digunakan untuk membangun sebuah lingkungan sistem yang cerdas.

Perangkat dasar utama untuk membangun sistem Pervasive adalah sensor, aktuator, microprossesor dan jaringan komunikasi tanpa kabel yang terintegrasi menjadi satu [7]. Kecerdasan pada pervasive computing dibangun melalui pengintegrasian semua komponen tersebut. Dalam hal ini, sensor digunakan oleh sistem pervasive untuk mengindra dan mengumpulkan informasi maupun isyarat dari lingkungan sistem, kemudian microprocessor memproses isyarat sesuai dengan fungsi sistem ini. Jika ada keputusan untuk melakukan proses adaptasi maka microprocessor akan memerintahkan aktuator melakukan perubahan lingkungan disesuaikan dengan syarat sistemnya. Jika sistem pervasive dibangun menggunakan peralatan yang tersebar, maka jaringan nirkabel/kabel digunakan untuk melakukan komunikasi antar peralatan tersebut. 
Dengan demikian pervasive system juga dapat digunakan untuk menciptakan bangunan cerdas pada domain pemakaian listrik oleh bangunan. la digunakan untuk membangun Smart Building yang mampu mengatur penggunaan listrik secara adaptif terhadap kebutuhan dan aktifitas pemakai [8]. Smart building yang kemudian disebut bangunan cerdas didefinisikan sebagai bangunan yang mampu mengelola penggunaan energi listrik digedungnya melalui mekanisme pengontrolan dan pengaturan menggunakan sensor untuk pengindraan dan aktuator untuk pengaktifan peralatan listrik disesuikan dengan fungsinya.

\section{Hasil dan Pembahasan}

\subsection{Analisa Ruang Keadaan Sistem Kelistrikan di Gedung}

Pemakaian listrik di gedung pada umumnya terbebani untuk menyediakan penerangan dan penghawaan udara yang sesuai, serta oleh peralatan listrik pendukung pelaksanaan aktifitas yang disesuaikan dengan fungsi ruangannya. Saklar listrik digunakan untuk mengaktifkan atau mematikan lampu maupun AC. Stop kontak digunakan sebagai perantara/penghubung antara sumber listrik dengan peralatan elektronik.

Seseorang yang memasuki suatu ruangan di bangunan, secara alami akan mengaktifkan peralatan listrik yang dibutuhkannya. Aktifitas yang dapat dilakukan seperti mengaktifkan lampu jika merasa ruangan yang dimasukinya gelap, mengaktifkan AC jika ruangan tersebut terasa panas, atau mengaktifkan peralatan listrik pendukung untuk membantunya melaksanakan aktifitas diruangan yang dimasuki. Semua aktifitas dilakukannya secara manual.

Smart Building disini mencoba menawarkan model interaksi baru antara penghuni bangunan dengan peralatan listrik yang dimilikinya. Pemahaman gedung tentang keadaan lingkungan sekitarnya membuat Smart Building bisa secara implisit berinteraksi dengan penghuni bangunan, kemudian berdasarkan interaksi ini, bangunan mengaktifkan/mematikan peralatan listrik. Sensor digunakan untuk interaksi implisit yang diperlukan. Metode yang digunakan membuat gedung paham akan penghuninya dalam context pemakaian listrik disana.

\subsection{Pemodelan Skalar Otomatis}

Tiga sub-sistem utama secaraumumyang mengkonsumsi energi listrik secara tetap pada suatu bangunan, yaitu kebutuhan peralatan listrik pada penerangan buatan, kebutuhan peralatan listrik untuk pengkondisian udara yang nyaman sebagai penunjang seseorang dapat beraktifitas di dalam suatu ruangan dan kebutuhan peralatan listrik lainnya yang berfungsi sebagai alat bantu dalam pelaksanaan aktivitas seseorang di dalam gedung.Sebuah bangunan yang cerdas terhadap pemakaian energi listrik dapat diciptakan jika gedung mampu paham terhadap keenam dimensi informasi. Desain model saklar otomatis untuk ketiga sub-sistem tersebut dapat dilihat pada Gambar 3, 4 dan 5. 


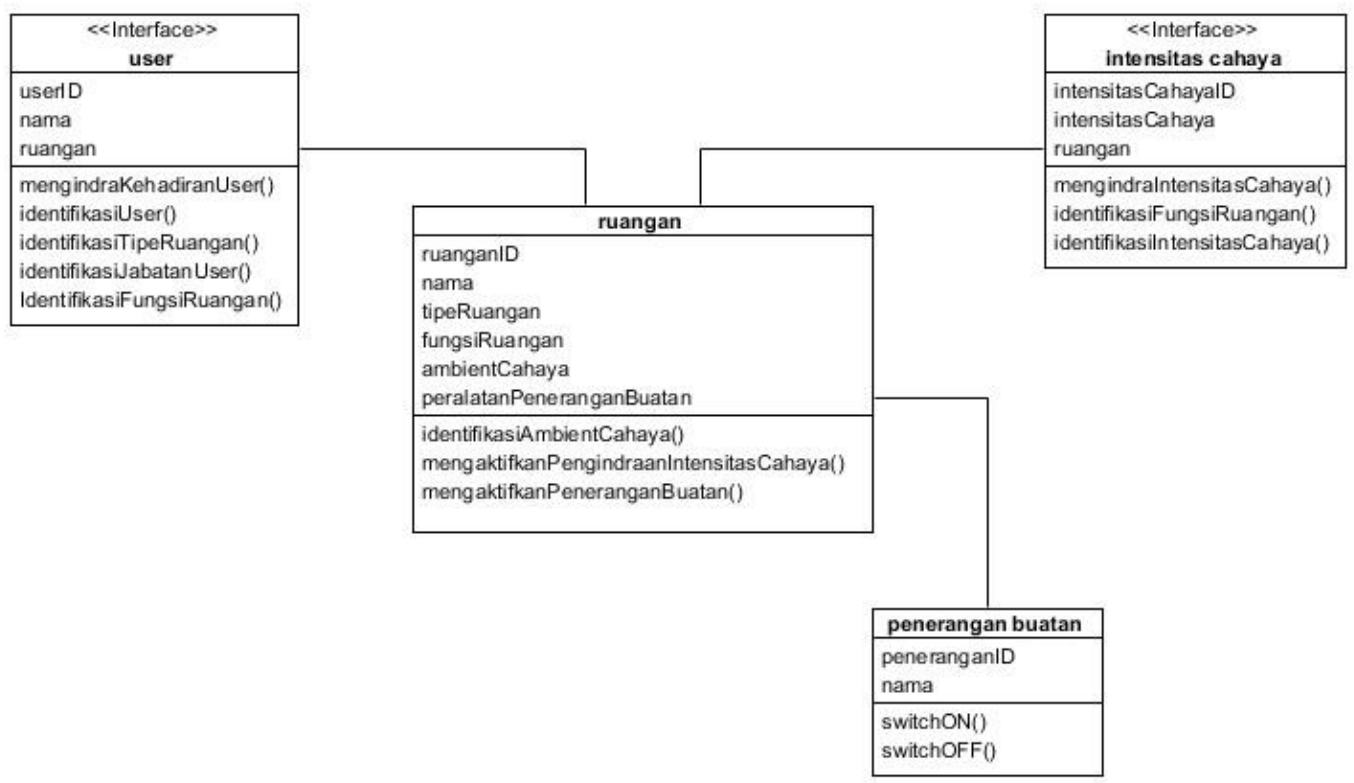

Gambar 3. Desain model saklar otomatis sistem penerangan ruangan di bangunan

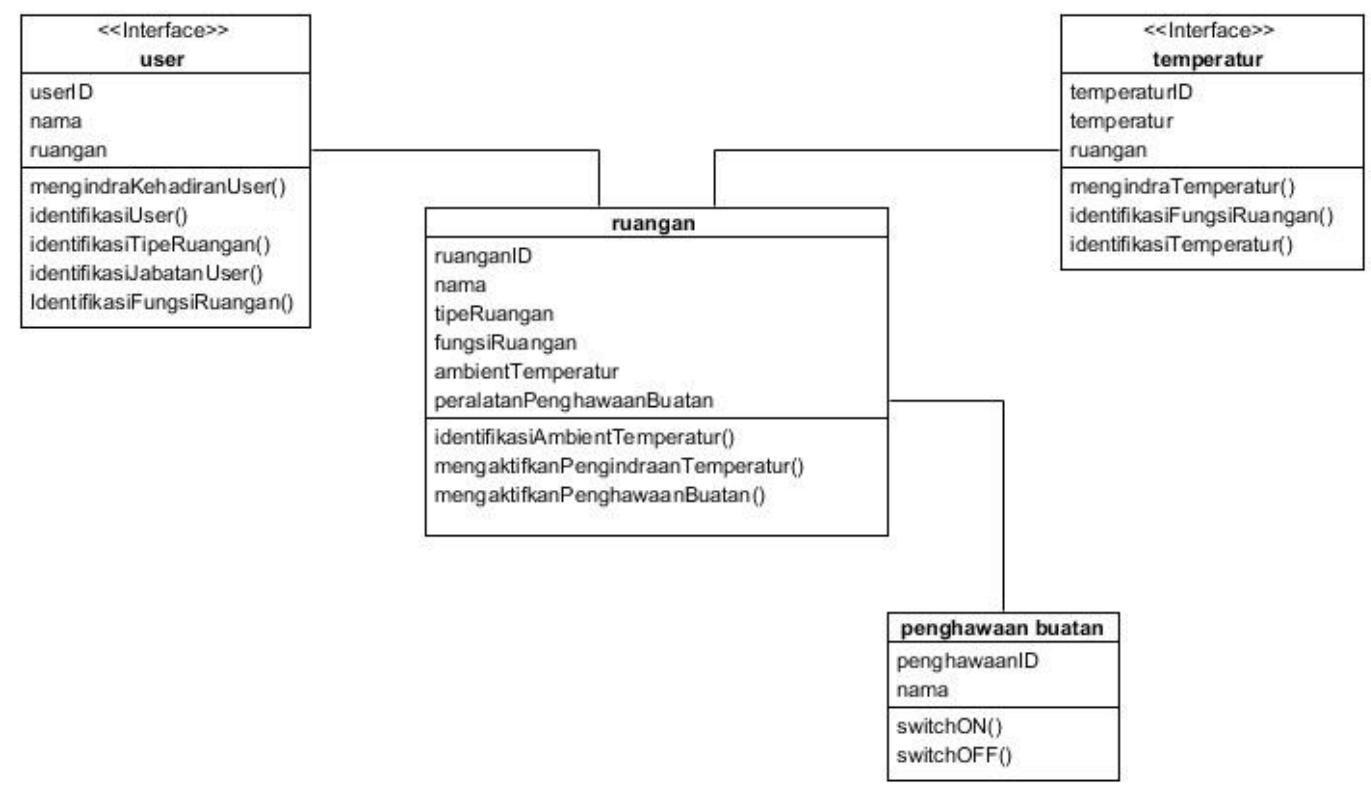

Gambar 4.Desain model saklar otomatis sistem pengkondisian udara ruangan di bangunan 


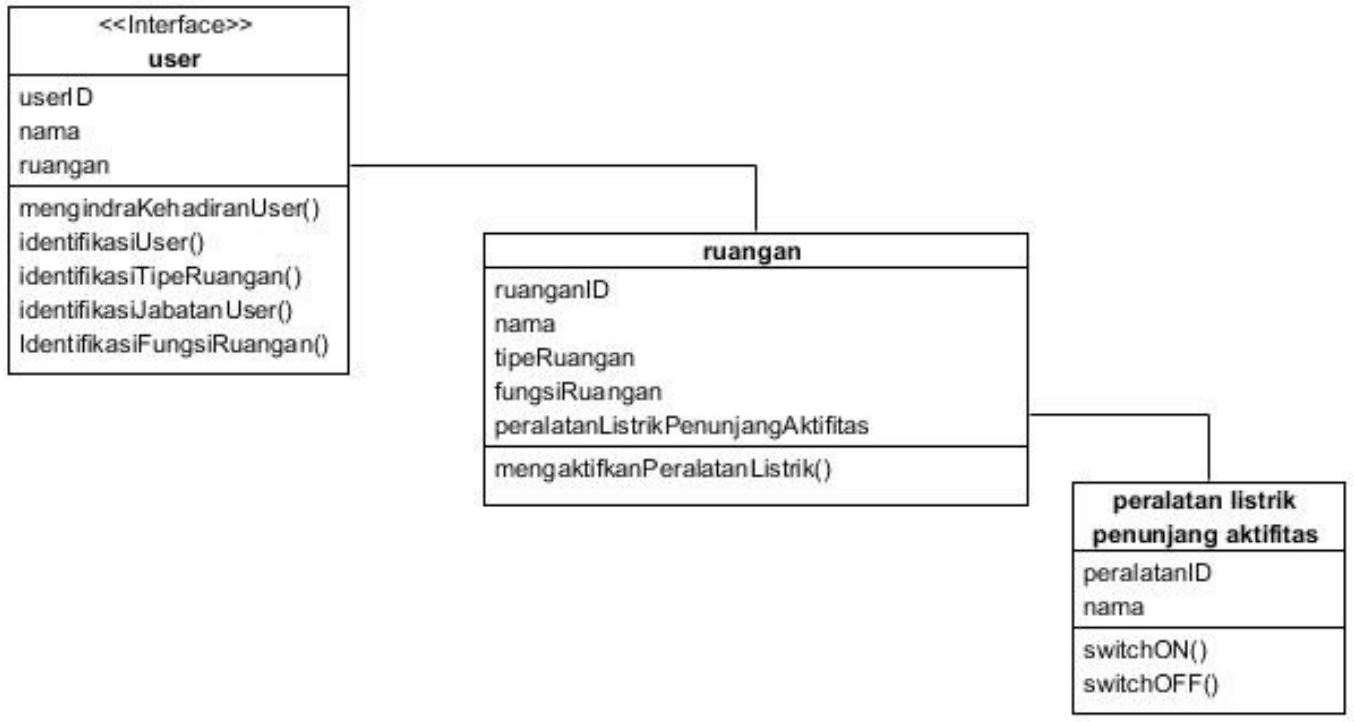

Gambar 5. Desain model saklar otomatis peralatan listrik pendukung aktifitas pada ruangan

\subsection{Simulasi Saklar Otomatis berbasis Mikrokontroler Arduino Mega 2560}

Simulasi saklar otomatis memvisualisasikan cara kerja saklar otomatis smart building di dalam mengendalikan penggunaan peralatan listrik pada ruangan di suatu gedung. Pengaturan metode kontrol saklar otomatis merujuk pada dimensi informasi smart building dan model desain diagram class diatas. Nilai informasi yang melekat pada penghuni gedung dan lingkungan fisik gedung seperti ditunjukkan pada Tabel 2 .

Tabel 2. Informasi yang akan mempengaruhi penggunaan peralatan listrik pada suatu ruangan

\begin{tabular}{lcc} 
& \multicolumn{2}{c}{ didalam gedung. } \\
\hline $\begin{array}{l}\text { Informasi yang harus dipahami } \\
\text { oleh smart building }\end{array}$ & Nilai beserta informasi yang diwakilinya \\
\cline { 2 - 3 } Keberadaan seseorang & 1 & 0 \\
\hline $\begin{array}{l}\text { Penerangan alami berdasarkan } \\
\text { matahari }\end{array}$ & Ada & Terang \\
\hline Suhu alami di dalam ruangan & Panas & Gelap \\
\hline Cahaya buatan utama & Dibutuhkan & Tidak dibutuhkan \\
\hline Suhu buatan di dalam ruangan & Dibutuhkan & Tidak dibutuhkan \\
\hline $\begin{array}{l}\text { Peralatan Listrik Penunjang } \\
\text { Aktifitas }\end{array}$ & Dibutuhkan & Tidak dibutuhkan \\
\hline
\end{tabular}

Smart building mampu membuat keputusan pemakaian peralatan listrik berdasarkan pengetahuan dengan cara mencocokan keadaan sesaat lingkungan dunia nyata di gedung dengan pengetahuan yang dimilikinya. Gambar 6,7 dan 8 adalah contoh kode program yang dibuat pada ardunio untuk ketiga sub-sistem dari sistem kelistrikan di gedung. 
(90) smart_building_2.2oke |Arduino 1.0.6

File Edit Sketch Tools Help

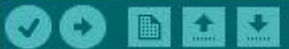

smart_building_2.20ke $\S$

lcd.print('R'),

lcd.print('E'),

lcd.print('s'),

lcd.print ('E'),

lcd.print ('P'),

lcd.print('s'),

lcd.print('I'),

lcd.print('0')

lcd.print ('N'),

lcd.print('I'),

lcd.print('s'):

/* context-aware untuk adaptasi peralatan listrik */

digitalwrite (53, Low) ;

Gambar 6. Contoh kode program saklar otomatis peralatan listrik pendukung aktifitas pada ruangan resepsionis.

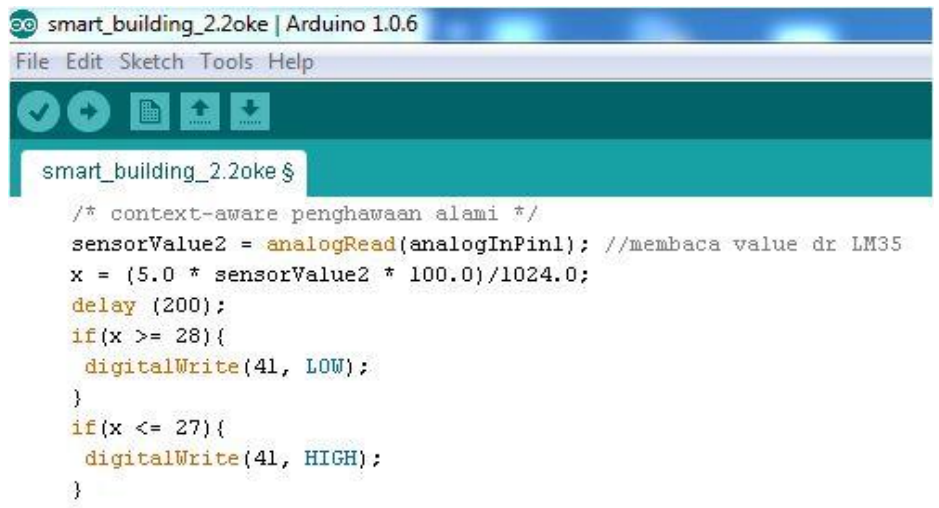

Gambar 7. Contoh kode program saklar otomatis sistem pengkondisian udara ruangan

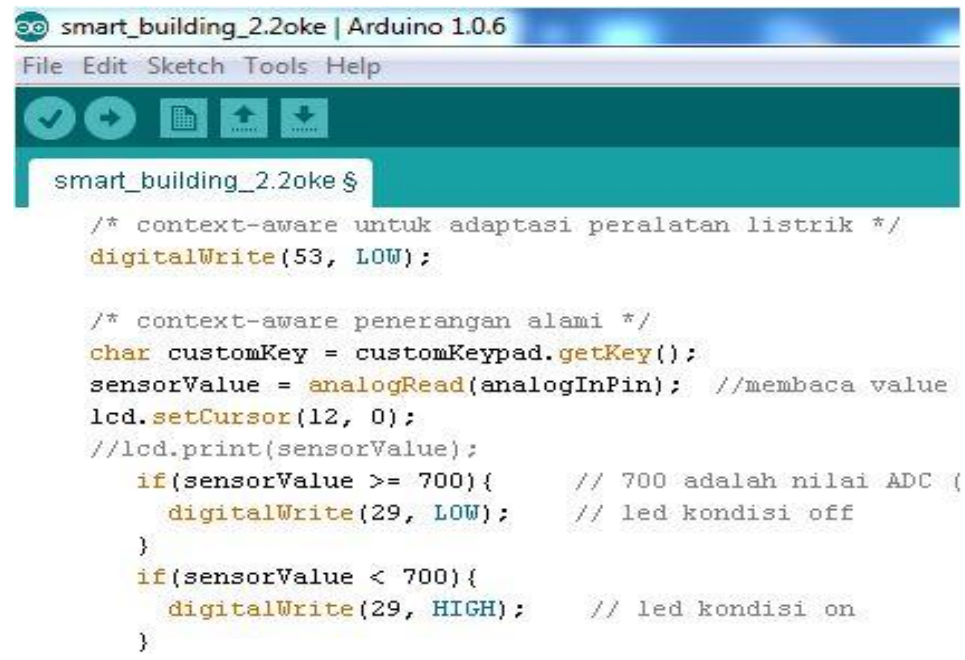

Gambar 8. Contoh kode programsaklar otomatis sistem penerangan ruangan di bangunan 
Saklar otomatis yang dimiliki smart building terdiri dari tiga modul utama untuk melakukan manajemen pemakaian peralatan listrik, yaitu modul context-aware penghuni bangunan, modul context-aware penerangan ruangan dan modul context-aware penghawaan ruangan. Sistem juga memiliki tiga modul yang dikelola berdasarkan kepekaan smart building terhadap nilai informasi untuk keputusan adaptasi pemakaian listrik dibangunan yang terdiri dari modul penerangan buatan, modul penghawaan buatan dan modul peralatan pendukung aktifitas yang disesuaikan dengan fungsi ruangannya. Agregasi dari keseluruhan modul membentuk sebuah model saklar otomatis untuk smart building dalam konteks penggunaan peralatan listrik.

Sistem selalu memonitor kehadiran seseorang di sebuah ruangan. Deteksi kehadiran seseorang yang dilakukan oleh modul context-aware penghuni bangunan akan memicu aktivasi sistem saklar otomatis penggunaan peralatan listrik. Kepekaan smart building terhadap kehadiran seseorang di sebuah ruangan mengaktifkan proses penalaran kepekaan context penghuni dan lingkungan fisik ruangan bangunan. Modul context-aware penerangan ruangan digunakan untuk mengindra kualitas penerangan diruangan, sedangkan modul context-aware penghawaan ruangan digunakan untuk mengindra kualitas suhu udara di dalam ruangan.

Smart Building dapat mengatur adaptasi switch-on/switch-off peralatan listrik diruangan berdasarkan hasil penalaran dari ketiga modul context-aware. Modul penerangan buatan digunakan untuk switch-on/switch-off lampu, menggunakan modul penghawaan buatan untuk on/off AC dan menggunakan modul peralatan pendukung aktifitas untuk on/off peralatan pundukung aktifitas disesuaikan dengan fungsi ruangan di suatu gedung.

\section{Kesimpulan}

Simulasi saklar otomatis menunjukkan bahwa desain yang diterapkan bisa bekerja baik untuk paham akan lingkungan dunia nyata sistem kelistrikan di gedung. Syarat yang harus dipenuhi adalah melakukan pendefinisian dimensi informasi sistem kelistrikan secara eksplisit sehingga smart building mampu berinteraksi secara implisit dengan penghuni dan lingkungan fisik disekitarnya. Smart building kemudian menggunakan informasi sistem kelistrikan untuk melakukan manajemen pemakaian peralatan listrik yang dimilikinya.

Sistem dibuat dan diujikan hanya sebatas onboard pada mikrokontroler arduino mega 2560. Perlu dilakukan penelitian lebih lanjut untuk pengembangan prototype dengan teknologi Internet of things mengingat sesungguhnya peralatan listrik berada secara tersebar di ruangan gedung.

\section{Daftar Pustaka}

[1] T. Weng and Y. Agarwal, "From Buildings to Smart Buildings - Sensing and Actuation to Improve Energy Efficiency," IEEE Design and Test of Computers, vol. 29, pp. 36 - 44, August 2012.

[2] F. Masykur and F. Prasetiyowati, " Aplikasi Rumah Pintar (Smart Home) Pengendali Peralatan," Jurnal Teknologi Informasi dan IImu Komputer (JTIIK), vol. 3, pp. 51 - 58, Maret 2016.

[3] A. S. Romoadhon and D. R. Anamisa, "Sistem Kontrol Peralatan Listrik pada Smart Home Menggunakan Android," Jurnal Ilmiah Rekayasa, vol. 10, pp. 116 - 122, Oktober 2017.

[4] H. R. Iskandar, I. B. Prasetya, I. Arifin, and A. Triaji, "Prototipe Kendali Lampu Jarak Jauh untuk Home Automation Systems Berbasis Arduino Mega dan Android Application," in Seminar Nasional Informatika dan Aplikasinya (SNIA) 2017, Cimahi, 2017, pp. c55 - c61.

[5] S. K. Azifah and I. Waspada, "Rancang Bangun Smart Building Dalam Memantau Dan Mengendalikan Lampu Secara Realtime Berbasis Websocket," Jurnal AMIK JTC INFOKAM, vol. 13, pp. 27 - 38, September 2017.

[6] M. Weiser, "The Computer for the 21st Century," Scientific American Journal, pp. 78 - 89, September 1991.

[7] V. Raychoudhury, J. Cao, M. Kumar, and D. Zhang, "Middleware for Pervasive Computing : A Survey," Pervasive and Mobile Computing, vol. 9, pp. 177 - 200, 2013.

[8] T. A. Nguyen and M. Aiello, "Energy Intelligent Buildings Based on User Activity : A Survey," Energy and Buildings, vol. 56, pp. 244 - 257, 2013. 